\title{
Calf starter containing a blend of essential oils and prebiotics affects the growth performance of Holstein calves
}

\author{
Ting Liu, ${ }^{1}$ Hao Chen, ${ }^{1 *}$ Yan Bai, ${ }^{1}$ Jianping Wu, ${ }^{1} \dagger$ Shuru Cheng, ${ }^{1}$ Bing He, ${ }^{1}$ and David P. Casper ${ }^{2}$ \\ ${ }^{1}$ Faculty of Animal Science and Technology, Gansu Agricultural University, No. 1 Yingmen Village Anning, Lanzhou, Gansu, 730070, P. R. China \\ ${ }^{2}$ Casper's Calf Ranch, 4890 West Lily Creek Road, Freeport, IL 61032
}

\begin{abstract}
Essential oils extracted from specific plants can exhibit antimicrobial properties that make them potential antibiotic alternatives. The objective was to evaluate an essential oil and prebiotic combination (EOC) on the growth, development, and health status of growing neonatal calves. Forty Holstein newborn calves were blocked by birth date and alternately assigned to 1 of 2 treatments. Treatments were a pelleted calf starter (CS) without (control) or with EOC at $44.1 \mathrm{ppm}$. Calves were fed the experimental CS for ad libitum consumption from $3 \mathrm{~d}$ of age through the end of the 70-d experiment. Calves were fed $2 \mathrm{~L}$ of whole milk twice daily to $10 \mathrm{~d}$ of age, then $3 \mathrm{~L}$ twice daily through d 35, and then fed $3 \mathrm{~L}$ once daily with abrupt weaning occurring after $42 \mathrm{~d}$ of age. The average daily gain (0.78 and $0.87 \mathrm{~kg} / \mathrm{d}$ for control and EOC, respectively) was greater for calves fed EOC compared with calves fed the control. Calves fed EOC demonstrated greater dry matter intake $(1.63$ and $1.74 \mathrm{~kg} / \mathrm{d})$ compared with calves fed the control. Feed conversion ratio (0.62 and $0.65 \mathrm{~kg}$ of gain $/ \mathrm{kg}$ of dry matter intake) was greater for calves fed EOC compared with calves fed the control. At $70 \mathrm{~d}$ of age, calves fed EOC demonstrated increased body frame measurements (hip height, body length, heart girth, abdominal girth, and pastern) compared with calves fed the control. The incidence of scours score 4 (mild diarrhea) was 3.5 incidences lower for calves fed EOC compared with calves fed the control, whereas the incidence of scours score 5 (severe diarrhea) for calves fed EOC was 0.5 incidences lower than calves fed the control. Blood concentrations of IgG and $\operatorname{IgM}$ on $\mathrm{d} 14, \operatorname{IgA}$ on $\mathrm{d} 28$, and total serum protein on d 42 were all greater for calves fed EOC compared with calves fed the control. The blood volatile fatty

\footnotetext{
Received March 18, 2019.

Accepted November 7, 2019.

*Current address: Gan Su Ya Sheng Agricultural Research Institute

†Corresponding author: wujp@gsagr.ac.cn
} Co. Ltd., Lanzhou, Gansu, P.R. China.
\end{abstract}

acid concentrations were greater for calves fed EOC compared with calves fed the control, which indicated enhanced ruminal development. Total-tract digestibility of dry matter, crude protein, acid detergent fiber, neutral detergent fiber, starch, and many minerals were increased for calves fed EOC compared with calves fed the control. The inclusion of an EOC blend into a CS demonstrates promising benefits for enhancing calf growth, ruminal development, gut health, nutrient digestibility, and immunity. The use of an EOC blend can be a plausible alternative to feeding subtherapeutic antibiotics for improving calf performance, health, and immunity.

Key words: calf, essential oils, growth performance, oregano

\section{INTRODUCTION}

Antibiotics have existed for over $60 \mathrm{yr}$ and substantially benefited public health and livestock production. However, many countries have banned the feeding of antibiotics as growth promoters. The Chinese Ministry of Agriculture (Qiao et al., 2018) banned certain antibiotics; therefore, research identifying efficacious and economical antibiotic alternatives is needed. The neonatal calf has a critical need for antibiotic alternatives due to the numerous calfhood stresses and diseases that can potentially lead to high mortality (NAHMS, 2016). Several feed additives have been investigated for enhancing general health and performance (Kertz et al., 2017).

Prebiotics, probiotics, organic acids, phytogenic substances, and essential oils (EO) have been shown to improve gut health and immunity (Acamovic and Brooker, 2005; Calsamiglia et al., 2007). Oregano is an EO blend (thymol, carvacrol, and so on) that has broad antimicrobial activity, particularly against gram-positive bacteria, by disrupting the bacterial cell membrane (Botsoglou et al., 2002; Benchaar and Greathead, 2011) that can lead to improved nutrient digestion (Hernandez et al., 2004). The food industry commonly uses EO (Varel, 2002) because it is generally recognized as safe. 
The use of EO has promising benefits when fed to young calves for enhancing performance and health. However, until now, results have not been consistent concerning the effects of $\mathrm{EO}$ on animal performance, most likely because of variation in dosage and chemical structure of EO used, as well as differing ration compositions and animal physiology among studies (Schären et al., 2017). Hill et al. (2007) reported improved ADG, calf starter (CS) intake, and feed efficiency in preweaned calves fed a commercial EO combination (EOC). In contrast, Santos et al. (2015) reported no calf health or performance benefits when feeding a commercial EOC. Most recently, Froehlich et al. (2017) demonstrated a growth performance advantage when feeding an EOC at lower than recommended rates. Our hypothesis is that EOC can be used to enhance calf performance, gut health, and immunity when fed to neonatal calves. The objective was to determine if an inclusion of EOC in the CS could improve calf performance and nutrient utilization with fewer health challenges in Holstein dairy calves.

\section{MATERIALS AND METHODS}

\section{Animal and Experimental Design}

This experiment was conducted at the Lintao Huajia Animal Husbandry Co. Ltd., $100 \mathrm{~km}$ south of Lanzhou, Gansu, China. The experiment was conducted according to the Chinese Standards for the use and care of Research Animals (He et al., 2016) through the Gansu Agricultural University, Lanzhou, China. Forty Holstein calves (20 female and 20 male calves split equally across treatments) from a paternal halfsib family were sourced from the Huajia Dairy Farm, which is a commercial research dairy farm, and housed in individual calf pens bedded with straw under an open-sided naturally well-ventilated barn. Calves were blocked by birth date and alternately assigned to 1 of 2 experimental CS. Twenty calves received a pelleted CS feed without (control) or 20 calves received the same CS with an essential oil prebiotic (EOC) combination added at the rate of $44.1 \mathrm{ppm}$. The EOC contained a proprietary blend of EO (carvacrol, caryophyllene, p-cymete, cineole, terpinene, and thymol), prebiotic (arabinogalactons), and cobalt lactate (CoMax) and manufactured by Ralco Inc. (Rum-A-Fresh, Marshall, $\mathrm{MN})$. The ingredient composition of the experimental CS is given in Table 1. The ingredient formulation of the experimental CS was to meet or exceed the NRC (2001) nutrient requirements for calves during the first 2 mo of life. The experiment was conducted from November 15, 2015, through May 21, 2016. During this time frame the maximum, average, and minimum
Table 1. Ingredient composition of control calf starter ${ }^{1}$

\begin{tabular}{lc}
\hline Ingredient & $\begin{array}{c}\text { \% of mix } \\
\text { (DM basis) }\end{array}$ \\
\hline Corn, ground shelled & 48.34 \\
Molasses & 3.36 \\
Soybean meal, 43\% CP & 32.10 \\
Corn distillers grains with solubles & 10.26 \\
Rapeseed meal & 2.00 \\
Salt & 0.11 \\
Oil, soybean & 1.03 \\
Premix & 2.80 \\
Total & 100.0 \\
\hline
\end{tabular}

${ }^{1}$ Essential oil prebiotic combination calf starter was made by adding $44.1 \mathrm{ppm}$ of Rum-A-Fresh, Ralco Inc. (Marshall, MN).

temperatures were $26.7,1.1$, and $-25.6^{\circ} \mathrm{C}$, respectively, with a maximum, average, and minimum humidity of $66.7,51.9$, and $44.1 \%$. The experimental period was 70 d from date of birth and the calves were fed CS for ad libitum consumption starting $3 \mathrm{~d}$ after birth through the end of the study $(70 \mathrm{~d})$ with weaning occurring at $42 \mathrm{~d}$ of age.

At birth (d 0), calves had a blood sample collected for measurement of total serum protein (TSP). Calves were fed $2 \mathrm{~L}$ of colostrum at the morning and evening feedings for $2 \mathrm{~d}$. However, if a calf was born in the afternoon or evening this was considered $\mathrm{d} 1$ and it may have received only 1 feeding of colostrum before being blood sampled for the d 2 TSP measurements. Calves were fed $2 \mathrm{~L}$ of fresh whole milk after colostrum feeding to $10 \mathrm{~d}$ of age per feeding at 0800 and $1700 \mathrm{~h}$ (i.e., $2 \times / \mathrm{d}$ ). From d 11 to 35 , calves were fed $3 \mathrm{~L}$ of fresh whole milk per feeding (i.e., $2 \times /$ d). The weaning protocol was started on d 35 through d 42 by feeding calves $3 \mathrm{~L}$ of fresh whole milk once daily at $0800 \mathrm{~h}$ (i.e., $1 \times / d)$. Weaning occurred by discontinuing fresh whole milk feeding after $\mathrm{d} 42$. The fresh whole milk was produced by the lactating dairy cows at the Huajia Dairy operation and milk nutrient composition was measured weekly via an emulsion analyzer (model GT017830, Hangzhou Zhejian University U-Micron Technology Co. Ltd., Hangzhou, China) and the nutrient composition and variation is given in Table 2 .

Table 2. Nutrient composition of fresh whole milk fed to calves

\begin{tabular}{lcc}
\hline Measurement & Concentration & SD \\
\hline $\mathrm{N}$ & 164 & - \\
TS, \% & 13.18 & 0.76 \\
Milk fat, \% & 3.83 & 0.24 \\
Milk protein, \% & 2.95 & 0.47 \\
SNF, \% & 9.35 & 0.64 \\
Lactose, \% & 4.85 & 0.46 \\
Ash, \% & 0.71 & 0.08 \\
Freezing point, ${ }^{\circ} \mathrm{C}$ & -0.55 & 0.20 \\
Density, g/mL & 1.03 & 0.003 \\
\hline
\end{tabular}




\section{Feed Intake and Analysis}

Starting on d 3, the amounts of CS offered and amounts refused were recorded daily using a digital scale. Samples of CS were collected weekly and composited at the end of the study into monthly lots (10 each for control and EOC, respectively) for nutrient analyses. At wk 8 of age, a single CS sample and individual fecal samples were collected from each calf. Fecal samples were collected at various times of the day when sufficient manure was available to be sampled without the contamination of bedding. All feed and 8 -wk fecal samples were dried at $60^{\circ} \mathrm{C}$ and ground to pass through a 1-mm screen. Samples were analyzed using the following AOAC International (2016) methods for DM (930.15), CP (990.03), NDF (Van Soest et al., 1991), ADF (973.18), starch (Hall, 2009), Ca (985.01), $\mathrm{P}$ (985.01), Mg (985.01), K (985.01), Na (985.01), Cl, S (985.01), Mn (985.01), Fe (985.01), Cu (985.01), Zn (985.01), and acid insoluble ash (955.03). Dry matter intake was calculated as a 7-d weekly average on a daily feed intake basis times DM content of milk and CS, whereas apparent total-tract nutrient digestibilities were calculated using acid insoluble ash as an internal digestibility marker.

\section{Body Weight, Fecal, and Health Measurements}

Body weights were taken weekly using a platform scale (model XK3190-A12 \pm E, Shanghai Yaohua Co., Ltd., Shanghai, China) before the morning feeding. Body frame measurements were taken at $0,14,28,42$, 56 , and $70 \mathrm{~d}$ and included withers height (WH), body length (BL), heart girth (HG), abdominal girth (AG), and cannon bone (CB) measured using a Biltmore stick and flexible ruler (Jiangsu Animal Husbandry Veterinary Equipment Manufacturing Co., Ltd., Jiangsu, China).

Fecal consistency scores were recorded every day for each calf throughout the trial based on a 1- to 5-point scale $(1=$ stiff, $2=$ pasty, $3=$ normal, $4=$ loose, and 5 = watery; Stamey et al., 2012). Calves were monitored daily for body temperature and respiration rate. Any abnormality or health condition that arose was treated immediately with appropriate medicines and treatments were recorded.

Blood samples were collected from the jugular vein of all calves after the morning feeding at 0, 2, 14, 28, 42, 56, and $70 \mathrm{~d}$. An additional blood sample was collected at wk 5 of age for the measurement of VFA concentrations as an index of rumen development. Blood samples were collected using a 10-mL Vacutainer serum separation tube with an 18-gauge needle (Becton, Dickinson and
Company, Franklin Lakes, NJ). Samples were allowed to clot and serum was harvested by centrifugation at $2,000 \times g$ for $10 \mathrm{~min}$ at $20^{\circ} \mathrm{C}$ and stored frozen in $5-\mathrm{mL}$ polystyrene tubes for measurement of immunity indexes (TSP, IgA, IgM, and IgG) using an enzyme standard instrument (Beijing Liuyi Biological Technology Co. Ltd., Beijing, China) with ELISA Kit (Wuhan BeiYin Biological Technology Co. Ltd., Wuhan, China).

The blood serum samples collected during wk 5 were analyzed for VFA concentrations via GC (model 6890 N, Agilent Technology, Wilmington, DE). Samples were prepared according to the procedures of Oba and Allen (2003) with some modifications. The column used for the chromatographic separations was a non-bonded poly (biscyanopropyl siloxane) phase that was a $30 \mathrm{~m} \times$ $0.32 \mathrm{~mm} \times 0.25 \mu \mathrm{m}$ film thickness, fused-silica column (SP-3560; Sigma-Aldrich, St. Louis, MO). Nitrogen was used as the carrier gas, with a split ratio of 40:1 and column flow of $2.0 \mathrm{~mL} / \mathrm{min}$. Injector temperature was set at $220^{\circ} \mathrm{C}$. The initial oven temperature was programmed at $120^{\circ} \mathrm{C}$ and maintained for $3 \mathrm{~min}$, then increased to $180^{\circ} \mathrm{C}$ at $10^{\circ} \mathrm{C} / \mathrm{min}$, and held at $180^{\circ} \mathrm{C}$ for $1 \mathrm{~min}$. The flame ionization detector was maintained at $250^{\circ} \mathrm{C}$.

\section{Statistical Analysis}

All data were checked for normality and outliers using the UNIVARIATE procedure of SAS (version 9.4, SAS Institute Inc., Cary, NC) before any statistical analyzes were conducted. All data were subjected to least squares ANOVA for a completely random design having 2 treatments via the PROC MIXED procedure of SAS (version 9.4, SAS Institute Inc.) with study day as a repeated measure ANOVA (Steel and Torrie, 1980). The statistical model used was

$$
Y_{i j}=\mu+T_{i}+D_{i}+\left(T_{i} \times D_{i}\right)+e_{i j},
$$

where $Y_{i j}=$ dependent variable, $\mu=$ overall mean, $T_{i}$ $=$ treatment, $\mathrm{D}_{\mathrm{i}}=$ day, $\mathrm{T}_{\mathrm{i}} \times \mathrm{D}_{\mathrm{i}}=$ treatment by week, and $\mathrm{e}_{\mathrm{ij}}=$ is the random error. Treatment, day, and treatment $\times$ day interactions were considered to be fixed effects whereas study day $\left(D_{i}\right)$ was considered a repeated measurement in time having an autoregressive covariance structure. Birth weight was tested as a covariate but did not improve statistical significance $(P$ $>0.15)$ and therefore was eliminated from the model. Calf starter intake, whole milk consumed, and total DMI were first pooled by time period (study day) and then statistically analyzed. Significance was declared at $P<0.05$ and highly significant at $P<0.01$ and trends at $0.05 \leq P \leq 0.10$. 


\section{RESULTS AND DISCUSSION}

\section{Milk and Feed Analyses}

The milk fat, protein, and TS composition of the fresh whole milk (Table 2) was typical of lactating Holstein dairy cows (NRC, 2001). The lactating dairy herd maintains SCC that are within regulatory limits for the production and marketing of whole milk. The fresh whole milk fed to the calves was not pasteurized.

The nutrient concentrations of both experimental CS met or exceeded formulation expectations to provide the nutrients to meet or exceed the NRC (2001) nutrient guidelines for growing calves (Table 3). The CP of the experimental CS was formulated to be greater than the CP concentration required by NRC (2001) to ensure enhanced frame growth. This was by design to ensure that CP was not limiting BW and frame growth. The CS are similar in nutrient concentration to the CS fed by Froehlich et al. (2017) who were evaluating a similar EOC product (water soluble) added to a 24:20 (CP:fat) all milk replacer.

\section{Growth Performance, ADG, DMI, and Feed Conversion}

No significant $(P<0.05)$ differences were observed in BW and body frame measurements on d 0 as calves were born and alternatively assigned to each of the experimental CS (Table 4). However, by $28 \mathrm{~d}$ of age, calves fed EOC had greater $(P<0.01) \mathrm{BW}$ than calves fed the control with these significant differences continuing throughout the study for 42,56 , and $70 \mathrm{~d}$ time points (Figure 1). By the end of the study, calves fed EOC were $6.15 \mathrm{~kg}$ heavier than calves fed the control, which was approximately an $11 \%$ improvement in BW gain. The ADG calculation (Table 4) indicated that calves fed EOC consistently $(P<0.05$ or $P<0.01)$ gained more BW from the start through the study's conclusion compared with calves fed the control. These data demonstrate that feeding a CS containing EOC will enhance calf BW and frame growth. In agreement, Froehlich et al. (2017) reported that calves fed $0.5 \mathrm{~g} /$ calf of a similar EOC blend in the milk replacer demonstrated enhanced growth rates compared with controlfed calves. However, Froehlich et al. (2017) concluded that inclusion rates of an EOC blend being fed to calves in previous research studies may have been too large of a dose that negatively affected calf performance (i.e., fed too much). These data and the literature suggest that feeding an EO or EOC blend will enhance growth performance when fed at an appropriate rate.

The DMI were similar $(P>0.05)$ for calves fed both CS during the initial week (d 3 to 7; Table 5). However,
Table 3. Nutrient composition (\% of DM basis) of the experimental calf starter without (control) or with an essential oil prebiotic combination (EOC)

\begin{tabular}{lcc}
\hline & \multicolumn{2}{c}{ Calf starter } \\
\cline { 2 - 3 } Nutrient & Control & EOC \\
\hline $\mathrm{N}$ & 10 & 10 \\
$\mathrm{DM}, \%$ & 92.7 & 93.2 \\
$\mathrm{ME},{ }^{\mathrm{M}} \mathrm{MJ} / \mathrm{kg}$ & 2.95 & 2.95 \\
$\mathrm{CP} \%$ & 24.3 & 24.2 \\
$\mathrm{ADF}, \%$ & 7.86 & 7.86 \\
$\mathrm{NDF}, \%$ & 17.5 & 17.6 \\
Fat, \% & 4.72 & 4.73 \\
$\mathrm{Ca}, \%$ & 0.80 & 0.79 \\
$\mathrm{P}, \%$ & 0.46 & 0.46 \\
$\mathrm{Se}, \%$ & 0.35 & 0.33 \\
\hline
\end{tabular}

${ }^{1}$ Calculated from NRC, 2001.

during the second week (d 8 to 14), calves fed EOC CS consume greater $(P<0.05)$ DMI compared with calves fed the control. Further, significant $(P<0.01)$ differences were observed between calves fed EOC and calves fed the control in DMI, which continued throughout the 70-d study. In addition, calves feed EOC had greater ADG compared with calves fed the control for the 70 $\mathrm{d}(P<0.05)$ and feed conversion ratio was improved for calves fed EOC compared with the calves fed the control for the time periods of 57 to $70 \mathrm{~d}(P<0.05)$ and 0 to $70 \mathrm{~d}(P<0.01$; Table 5$)$. These results demonstrate that feeding EOC will enhance DMI. These improvements might be associated with the volatile and aromatic compounds of EO. Calsamiglia et al. (2007) reported that EO are a diverse group of secondary plant metabolites that contain naturally occurring volatile

Table 4. Body weight, BW gain, and ADG for calves fed a calf starter without (control) or with an essential oil prebiotic combination (EOC)

\begin{tabular}{llcc}
\hline & \multicolumn{2}{c}{ Calf starter } & \\
\cline { 2 - 3 } Measurement & Control & EOC & SEM \\
\hline BW, kg & & & \\
N & 20 & 20 & - \\
d 0 & 42.3 & 43.7 & 0.97 \\
d 14 & 49.3 & 51.2 & 0.97 \\
d 28 & 58.2 & $61.8^{* *}$ & 0.97 \\
d 42 & 69.4 & $73.9^{* *}$ & 0.97 \\
d 56 & 82.3 & $88.1^{* *}$ & 0.97 \\
d 70 & 96.7 & $104.2^{* *}$ & 0.97 \\
Total gain, kg & 54.4 & $60.6^{* *}$ & 0.23 \\
ADG, kg/d & & & \\
d 0-14 & 0.50 & $0.54^{*}$ & 0.01 \\
d 15-28 & 0.64 & $0.76^{* *}$ & 0.01 \\
d 29-42 & 0.80 & $0.86^{* *}$ & 0.01 \\
d 43-56 & 0.92 & $1.01^{* *}$ & 0.02 \\
d 57-70 & 1.03 & $1.15^{* *}$ & 0.02 \\
d 0-70 & 0.78 & $0.87^{* *}$ & 0.003 \\
\hline
\end{tabular}

*Means within the same row differ, $P<0.05$.

** Means within the same row differ, $P<0.01$. 
components that support smell and stimulate orexis and taste of plants. A previous study had demonstrated the EO palatability effect (Franz et al., 2010). However, Chapman et al. (2016) evaluated the taste preferences of 6 weaned dairy heifers, which indicated these heifers preferred diets without cinnamaldehyde but that DMI was not negatively affected regardless of the concentration of cinnamaldehyde provided. Santos et al. (2015) reported that calves supplemented with a blend of EO were similar in CS DMI compared with control-fed calves. However, those results are in contrast to data reported by Hill et al. (2007) and Froehlich et al. (2017) that demonstrated a commercial EOC blend actually increased DMI and feed conversion ratio. Vakili et al. (2013) also stated that the effects of EO on DMI might vary with the EO source, the type of diet, diet interactions, or adaptations of rumen microbial population to the different EO.

\section{Fecal Scores}

Daily fecal scores were tallied for total incidences by calf (Table 6). A fecal score of 1 was not recorded during the study, which indicates that gut health was being consistently challenged. At $70 \mathrm{~d}$ of age, the number of score 4 mild diarrhea occurrences was 3.5 occurrences lower for calves fed EOC compared with calves fed the control $(P<0.01)$. The number of score 5 severe diarrhea occurrences for calves fed EOC was 0.5 occurrences lower than calves fed the control $(P<0.05)$. Similar results were reported by Froehlich et al. (2107), demonstrating that fecal scores by calves fed EOC were greater than calves fed the control $(P<0.05)$. Oregano oil contains phenolic structures that can inhibit specific pathogenic microorganisms, such as gram-negative

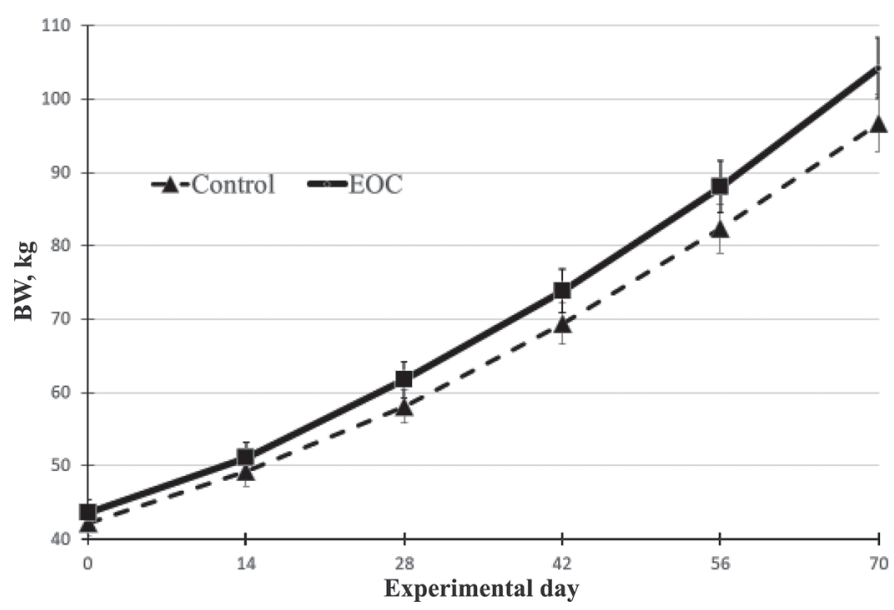

Figure 1. Body weight of calves fed a calf starter without (control) or with an essential oil prebiotic combination (EOC). Data are LSM, and error bars represent SEM.
Table 5. Total DMI (milk replacer plus calf starter) for calves fed a calf starter without (control) or with an essential oil prebiotic combination (EOC)

\begin{tabular}{lccc}
\hline & \multicolumn{2}{c}{ Calf starter } & \\
\cline { 2 - 3 } Measurement & Control & EOC & SEM \\
\hline $\mathrm{N}$ & 20 & 20 & \\
DMI, kg/d & & & \\
d 0-7 & 0.52 & 0.53 & 0.013 \\
d 8-14 & 0.77 & 0.79 & 0.013 \\
d 15-21 & 0.99 & 1.01 & 0.013 \\
d 22-28 & 1.13 & $1.18^{* *}$ & 0.013 \\
d 29-35 & 1.44 & $1.54^{* *}$ & 0.013 \\
d 36-42 & 1.58 & $1.68^{* *}$ & 0.013 \\
d 43-49 & 1.69 & $1.80^{* *}$ & 0.013 \\
d 50-56 & 2.08 & $2.21^{* *}$ & 0.013 \\
d 57-70 & 2.41 & $2.53^{* *}$ & 0.013 \\
d 0-70 & 2.74 & $2.90^{* *}$ & 0.013 \\
Average, d 0-70 & 1.63 & $1.71^{* *}$ & 0.01 \\
Feed efficiency, kg of gain/kg & & & \\
of DMI & & & \\
d 0-14 & 6.52 & 6.12 & 0.26 \\
d 15-28 & 1.94 & 2.05 & 0.06 \\
d 29-42 & 0.79 & 0.77 & 0.01 \\
d 43-56 & 0.45 & $0.47 \dagger$ & 0.01 \\
d 57-70 & 0.37 & $0.40^{*}$ & 0.01 \\
d 0-70 & 0.62 & $0.65^{* *}$ & 0.01 \\
\hline
\end{tabular}

$\dagger$ Means within the same row differ, $P<0.10$.

*Means within the same row differ, $P<0.05$.

**Means within the same row differ, $P<0.01$.

bacteria, Escherichia, and Salmonella Typhimurium (Benchaar et al., 2008). Gilling et al. (2019) reported antimicrobial efficacy of plant EO (lemongrass, cinnamon, and oregano EO) against Escherichia coli. The EO and their active components demonstrated statistically significant $>5.0 \log _{10}$ reductions within 1 to 10 min. Moreover, Benchaar et al. (2008) suggested that certain EO may have the ability to inhibit parasites, such as cryptosporidium, coccidia, and nematodes. The resulting improvement in the intestinal gut health environment may inhibit parasites, which may decrease diarrhea. However, Pempek et al. (2018) reported the EO (cinnamaldehyde) had no effect on diarrhea incidence, but the risk of navel inflammation was significantly lower for calves that received cinnamaldehyde compared with calves fed the control.

\section{Frame Measurements}

At d 28, calves fed EOC demonstrated greater $(P<$ 0.01) WH, BL, and AG body frame measurements than calves fed the control (Table 7). However, by the end of the 70-d experiment, calves fed EOC demonstrated greater $(P<0.01)$ overall growth of $\mathrm{WH}, \mathrm{BL}, \mathrm{HG}, \mathrm{AG}$, and $\mathrm{CB}$ than calves fed the control. The increased BW, $\mathrm{WH}$, and BL gains from d 28 to the end of the study were greater $(P<0.01)$ for calves fed EOC compared 
Table 6. The occurrences of diarrhea by calves fed a calf starter without (control) or with an essential oil prebiotic combination (EOC)

\begin{tabular}{lccc}
\hline & \multicolumn{2}{c}{ Calf starter } & \\
\cline { 2 - 3 } Diarrhea level & Control & EOC & \multirow{2}{*}{ SEM } \\
\hline Score 1 (times) & 0.0 & 0.0 & - \\
Score 2 (times) & 3.0 & 2.9 & 0.07 \\
Score 3 (times) & 55.0 & $59.1^{* *}$ & 0.22 \\
Score 4 mild (times) & 12.3 & $8.8^{* *}$ & 0.18 \\
Score 5 severe (times) & 0.8 & $0.3^{*}$ & 0.13
\end{tabular}

*Means within the same row differ, $P<0.05$.

** Means within the same row differ, $P<0.01$.

with calves fed the control. By d 28, calves fed EOC demonstrated greater $(P<0.05)$ AG gain than calves fed the control and this advantage carried through the end of the study. At weaning time on d 42, calves fed EOC demonstrated greater $(P<0.01)$ CB gains than calves fed the control, which continued through d 56 and 70. In addition, HG gains were greater $(P<0.05)$ for calves fed EOC than calves fed the control from $d$ 42 to 70 .

In agreement with these data, Froehlich et al. (2017) reported that the calves fed $0.5 \mathrm{~g} / \mathrm{d}$ EOC demonstrated greater body frame measurement gains compared with calves fed the control or greater rates of EOC. Calves fed $0.5 \mathrm{~g}$ of EOC were greater than calves fed $1.5 \mathrm{~g}$ of EOC in BL gains $(P<0.05)$. Gains in $\mathrm{WH}, \mathrm{HW}$, and $\mathrm{HH}$ were greater for calves fed EOC at $0.5 \mathrm{~g} / \mathrm{d}$ compared with calves fed the control $(P<0.05$; Froehlich et al., 2017). Santos et al. (2015), who fed lower amounts of EOC, reported increased frame growth. These data and the literature suggest that feeding an EO or EOC blend will enhance frame growth.

\section{Nutrient Digestibility}

Calves fed EOC demonstrated greater apparent total-tract nutrient digestibilities of DM, ADF, NDF, starch, $\mathrm{Na}, \mathrm{Mg}, \mathrm{P}, \mathrm{S}, \mathrm{K}, \mathrm{Ca}, \mathrm{Cl}, \mathrm{Mn}, \mathrm{Fe}, \mathrm{Cu}$, and $\mathrm{Zn}$ compared with calves fed the control $(P<0.01$; Table $8)$. Because whole milk and CS are highly digestible, small differences in nutrient intake and excretion can result in big changes in nutrient digestibility in combination with laboratory analytical error for nutrients and markers. The lipophilic components of carvacrol and thymol, which make up oregano oil, are thought to exert an inhibitory effect on specific rumen microorganisms (Zhou et al., 2020). A shift in ruminal microflora through inhibiting pernicious bacteria has the potential to increase CS nutrient digestibility. Furthermore, Mendel et al. (2017) reported the antioxidative activity of EO contributes to the protection of feed lipids from oxidative damage, enhancing the quality of ingested feed. Oregano oil also contains phenolic structures that can inhibit specific pathogenic microorganisms, such as the gram-negative bacteria, Escherichia, and Salmonella Typhimurium (Benchaar et al., 2008). Benchaar et al. (2006) reported that DMI was higher for steers fed EO compared with those fed without EO (6.30 vs. 5.85 $\mathrm{kg} / \mathrm{d}, P<0.05)$. Ornaghi et al. (2017) reported that DM and nutrient intakes were higher and increased linearly $(P<0.05)$ with dosage level in young bulls fed EO independent of the type. Kolling et al. (2018) reported oregano EO tended to increase the total-tract apparent $\mathrm{CP}$ digestibility coefficient. However, a contrasting report suggested that oregano EO fed to ruminants

Table 7. Body frame measurements of withers height, body length, heart girth, abdominal girth, and cannon bone circumference for calves fed a calf starter without (control) or with an essential oil prebiotic combination (EOC)

\begin{tabular}{|c|c|c|c|}
\hline \multirow[b]{2}{*}{ Measurement } & \multicolumn{2}{|c|}{ Calf starter } & \multirow[b]{2}{*}{ SEM } \\
\hline & Control & EOC & \\
\hline $\mathrm{N}$ & 20 & 20 & - \\
\hline \multicolumn{4}{|c|}{ Withers height, cm } \\
\hline d 0 & 82.1 & 84.5 & 0.86 \\
\hline d 14 & 84.1 & 86.6 & 0.86 \\
\hline d 28 & 86.2 & $89.7^{* *}$ & 0.86 \\
\hline d 42 & 89.2 & $92.7^{* *}$ & 0.86 \\
\hline d 56 & 92.3 & $96.7^{* *}$ & 0.86 \\
\hline d 70 & 96.7 & $101.9^{* *}$ & 0.86 \\
\hline Gain 0-70 d & 14.1 & $17.7^{* *}$ & 0.12 \\
\hline \multicolumn{4}{|c|}{ Body length, cm } \\
\hline d 0 & 80.9 & 83.3 & 1.09 \\
\hline d 14 & 93.0 & 85.3 & 1.09 \\
\hline d 28 & 86.0 & $89.3^{* *}$ & 1.09 \\
\hline d 42 & 90.1 & $93.4^{* *}$ & 1.09 \\
\hline d 56 & 94.0 & $98.4^{* *}$ & 1.09 \\
\hline d 70 & 96.7 & $104.6^{* *}$ & 1.09 \\
\hline Gain 0-70 d & 18.0 & $21.3^{* *}$ & 0.17 \\
\hline \multicolumn{4}{|l|}{ Heart girth, $\mathrm{cm}$} \\
\hline d 0 & 80.5 & 81.8 & 0.70 \\
\hline d 14 & 83.5 & 84.7 & 0.70 \\
\hline d 28 & 85.6 & 86.9 & 0.70 \\
\hline d 42 & 88.6 & $90.8^{*}$ & 0.70 \\
\hline d 56 & 92.9 & $96.1^{* *}$ & 0.70 \\
\hline d 70 & 97.5 & $101.8^{* *}$ & 0.70 \\
\hline Gain 0-70 d & 17.0 & $20.0^{* *}$ & 0.13 \\
\hline \multicolumn{4}{|c|}{ Abdominal girth, $\mathrm{cm}$} \\
\hline d 0 & 78.6 & 79.8 & 0.81 \\
\hline d 14 & 81.5 & 82.7 & 0.81 \\
\hline d 28 & 83.8 & $85.9^{*}$ & 0.81 \\
\hline d 42 & 86.9 & $89.8^{* *}$ & 0.81 \\
\hline d 56 & 92.5 & $98.2^{* *}$ & 0.81 \\
\hline d 70 & 96.6 & $103.4^{* *}$ & 0.81 \\
\hline Gain 0-70 d & 18.0 & $23.7^{* *}$ & 0.23 \\
\hline \multicolumn{4}{|c|}{ Cannon bone, $\mathrm{cm}$} \\
\hline d 0 & 10.8 & 11.3 & 0.23 \\
\hline d 14 & 10.8 & 11.3 & 0.23 \\
\hline d 42 & 10.8 & 11.4 & 0.23 \\
\hline d 42 & 11.2 & $12.3^{* *}$ & 0.23 \\
\hline d 56 & 12.1 & $13.3^{* *}$ & 0.23 \\
\hline d 70 & 12.8 & $14.1^{* *}$ & 0.23 \\
\hline Gain 0-70 d & 2.80 & $2.85^{* *}$ & 0.06 \\
\hline
\end{tabular}

* Means within the same row differ, $P<0.05$.

** Means within the same row differ, $P<0.01$. 
Table 8. Nutrient digestibility by calves fed a calf starter without (control) or with an essential oil prebiotic combination (EOC) at 8 wk of age

\begin{tabular}{lccc}
\hline & \multicolumn{2}{c}{ Calf starter } & \\
\cline { 2 - 3 } Nutrient & Control & EOC & SEM \\
\hline $\mathrm{N}$ & 20 & 20 & - \\
$\mathrm{DM}, \%$ & 88.6 & $92.2^{* *}$ & 0.30 \\
$\mathrm{CP}, \%$ & 86.7 & $91.9^{* *}$ & 0.46 \\
$\mathrm{ADF}, \%$ & 48.1 & $66.0^{* *}$ & 1.02 \\
$\mathrm{NDF}, \%$ & 49.2 & $66.7^{* *}$ & 1.33 \\
$\mathrm{Starch}, \%$ & 98.5 & $99.4^{* *}$ & 0.05 \\
$\mathrm{Na}, \%$ & 91.2 & $95.8^{* *}$ & 0.31 \\
$\mathrm{Mg}, \%$ & 58.6 & $71.6^{* *}$ & 1.16 \\
$\mathrm{P}, \%$ & 85.1 & $90.0^{* *}$ & 0.55 \\
$\mathrm{~S}, \%$ & 70.3 & $80.6^{* *}$ & 0.95 \\
$\mathrm{~K}, \%$ & 94.9 & $96.4^{* *}$ & 0.19 \\
$\mathrm{Ca}, \%$ & 67.7 & $78.0^{* *}$ & 1.23 \\
$\mathrm{Cl}, \%$ & 91.7 & $95.0^{* *}$ & 0.48 \\
$\mathrm{Mn}, \%$ & 56.2 & $72.2^{* *}$ & 1.46 \\
$\mathrm{Fe}, \%$ & 44.1 & $57.1^{* *}$ & 1.77 \\
$\mathrm{Cu}, \%$ & 45.9 & $62.5^{* *}$ & 1.75 \\
$\mathrm{Zn}, \%$ & 55.8 & $69.7^{* *}$ & 1.61 \\
\hline
\end{tabular}

**Means within the same row differ, $P<0.01$.

decreased feed conversions (Ünal and Kocabağli, 2014). Hristov et al. (2013) reported no effect on total-tract apparent nutrient digestibility, except NDF digestibility was slightly decreased by Origanum vulgare L. leaf treatments compared with control-fed lactating dairy cows. Ye et al. (2018) reported that an EO product (a commercial blend of cinnamaldehyde and garlic oil) decreased true OM digestibility (corrected for microbial $\mathrm{OM}$ in effluent) by $6.62 \%$ and tended $(P=0.11)$ to decrease NDF digestibility from Holstein cows. Thus, different EO can exert different effects on nutrient digestibility. These digestibility coefficients are within the ranges and similar to those recently published by Quigley (2019).

\section{Immunity}

The blood TSP, IgG, IgA, and IgM concentrations were similar $(P>0.05)$ for calves fed both treatments on the day of birth, but were greater for calves fed EOC compared with calves fed the control on d 14 for IgG and IgM, d 28 for IgA, and d 42 for TSP $(P<$ 0.01; Table 9). In the study reported by Froehlich et al. (2017), calves fed the $0.5 \mathrm{~g}$ of EOC had the greatest immunological response and improved growth. Feeding an EOC blend may enhance the immune system response to a pathogen challenge but may also modulate an immunological response due to an inflammatory response that can be detrimental to the growing calf because of energy being directed to the immune system versus growth (Froehlich et al., 2017). In that study, diarrhea was reduced through greater immunoglobulins, but
Table 9. Blood total serum protein and immunoglobulin concentrations of calves fed a calf starter without (control) or with an essential oil prebiotic combination (EOC)

\begin{tabular}{|c|c|c|c|}
\hline \multirow[b]{2}{*}{ Measurement } & \multicolumn{2}{|c|}{ Calf starter } & \multirow[b]{2}{*}{ SEM } \\
\hline & Control & EOC & \\
\hline $\mathrm{N}$ & 20 & 20 & - \\
\hline \multicolumn{4}{|l|}{ Total serum protein, $\mathrm{g} / \mathrm{L}$} \\
\hline 1 & 45.9 & 45.1 & 0.68 \\
\hline d 2 & 48.7 & 47.4 & 0.68 \\
\hline d 14 & 50.9 & 50.1 & 0.68 \\
\hline d 28 & 52.2 & 53.3 & 0.68 \\
\hline d 42 & 54.2 & $57.2^{* *}$ & 0.68 \\
\hline d 56 & 57.2 & $62.2^{* *}$ & 0.68 \\
\hline d 70 & 60.4 & $66.3^{* *}$ & 0.68 \\
\hline \multicolumn{4}{|l|}{$\mathrm{IgG}, \mathrm{mg} / \mathrm{dL}$} \\
\hline d 0 & 111.9 & 111.8 & 1.25 \\
\hline d 2 & 132.9 & 132.9 & 1.25 \\
\hline d 14 & 110.9 & $117.2^{* *}$ & 1.25 \\
\hline d 28 & 86.7 & $99.0^{* *}$ & 1.25 \\
\hline d 42 & 105.0 & $122.2^{* *}$ & 1.25 \\
\hline d 56 & 118.8 & $140.4^{* *}$ & 1.25 \\
\hline d 70 & 135.7 & $161.5^{* *}$ & 1.25 \\
\hline \multicolumn{4}{|l|}{$\mathrm{IgA}, \mathrm{mg} / \mathrm{dL}$} \\
\hline d 0 & 4.9 & 4.6 & 0.51 \\
\hline d 2 & 17.8 & 17.0 & 0.51 \\
\hline d 14 & 13.2 & 13.7 & 0.51 \\
\hline d 28 & 5.8 & $9.0^{* *}$ & 0.51 \\
\hline d 42 & 12.2 & $16.9^{* *}$ & 0.51 \\
\hline d 56 & 20.1 & $26.9^{* *}$ & 0.51 \\
\hline d 70 & 29.0 & $38.4^{* *}$ & 0.51 \\
\hline \multicolumn{4}{|l|}{$\mathrm{IgM}, \mathrm{mg} / \mathrm{dL}$} \\
\hline d 0 & 10.8 & 10.0 & 0.70 \\
\hline d 2 & 30.1 & 30.3 & 0.70 \\
\hline d 14 & 19.8 & $22.4^{* *}$ & 0.70 \\
\hline d 28 & 5.9 & $11.3^{* *}$ & 0.70 \\
\hline d 42 & 9.0 & $16.4^{* *}$ & 0.70 \\
\hline d 56 & 14.2 & $23.7^{* *}$ & 0.70 \\
\hline d 70 & 21.1 & $32.1^{* *}$ & 0.70 \\
\hline
\end{tabular}

**Means within the same row differ, $P<0.01$.

growth rates were enhanced. These data support the conclusion that EOC can enhance the immune status of growing Holstein calves.

\section{VFA}

Serum blood samples collected during wk 5 were analyzed for blood VFA concentrations as an indirect measurement of determining ruminal development (Table 10). Pentanoic acid was below detection limits. The blood VFA (acetic acid, propanoic acid, isobutyric acid, butyric acid, and isovaleric acid) concentrations for calves fed EOC were greater compared with calves fed the control $(P<0.01)$. The VFA are known to initiate epithelial and stimulate papillary growth within the rumen and butyrate is considered the most effective followed by propionate and acetate (Sakata and Tamate, 1979). Greater blood VFA concentrations would substantiate the conclusion that EOC is enhancing ruminal development, but further 
Table 10. Blood VFA concentrations of calves fed a calf starter without (control) or with an essential oil prebiotic combination (EOC)

\begin{tabular}{|c|c|c|c|}
\hline \multirow[b]{2}{*}{ Measurement } & \multicolumn{2}{|c|}{ Calf starter } & \multirow[b]{2}{*}{ SEM } \\
\hline & Control & EOC & \\
\hline $\mathrm{N}$ & 20 & 20 & - \\
\hline Acetic acid, $\mu \mathrm{mol} / \mathrm{L}$ & 639.1 & $735.1^{* *}$ & 11.19 \\
\hline Propanoic acid, $\mu \mathrm{mol} / \mathrm{L}$ & 39.3 & $57.5^{* *}$ & 1.45 \\
\hline Isobutyric acid, $\mu \mathrm{mol} / \mathrm{L}$ & 14.9 & $20.5^{* *}$ & 0.36 \\
\hline Butyric acid, $\mu \mathrm{mol} / \mathrm{L}$ & 44.4 & $59.7^{* *}$ & 1.08 \\
\hline Isovaleric acid, $\mu \mathrm{mol} / \mathrm{L}$ & 14.4 & $23.4^{* *}$ & 0.38 \\
\hline Total VFA, $\mu \mathrm{mol} / \mathrm{L}$ & 752.2 & $896.2^{* *}$ & 13.49 \\
\hline
\end{tabular}

**Means within the same row differ, $P<0.01$.

studies to directly measure ruminal development when calves are fed EOC should be conducted to confirm our indirect conclusion. In agreement, Lesmeister and Heinrichs (2004) reported that feeding a CS containing steam-flaked corn and more digestible starch increased ruminal epithelial metabolic activity, increased rumen VFA concentrations, or both, due to increased rumen papillae length and rumen wall thickness. Quigley et al. (1991) demonstrated greater blood VFA concentrations with greater feed intake. Thus, the greater VFA concentrations in this study are likely the result of both greater DMI (Table 5) and enhanced nutrient digestibility (Table 8) leading to more ruminal digestible nutrients to enhance ruminal VFA concentrations leading to enhanced blood VFA concentrations (Table 10) for calves fed EOC compared with calves fed the control. Our results contrast with data reported by Santos et al. (2015) who reported no significant differences in rumen propionate, butyrate, or acetate concentrations for calves when supplemented with and without EO. Hristov et al. (2013) reported that supplying oregano leaf to lactating dairy cows had no effect on ruminal VFA concentrations and microbial protein synthesis. The combination of $\mathrm{EO}$ and cobalt lactate in the EOC blend appears to synergistically enhance ruminal development. The enhancement in nutrient digestibilities (Table 8) by feeding the EOC blend would be expected to have more ruminal VFA production. Cobalt lactate is one component of the EOC blend. Cobalt lactate has been shown to improve fiber digestion (Poudel, 2016), which could lead to more acetate and butyrate.

\section{CONCLUSIONS}

Feeding calves an EOC blend contained in the CS improved BW and frame growth rates, enhanced ruminal development, and reduced the gut health challenges of raising neonatal Holstein calves. Feeding an EOC containing CS resulted in calves being $6.15 \mathrm{~kg}$ heavier and having a larger skeletal frame at the conclusion of the 70-d experimental period compared with controlfed calves. Calves fed the EOC demonstrated fewer gut health challenges (diarrhea) and an improved immune system (immunoglobulin). Feeding EOC may provide a natural viable alternative to antibiotics to minimize health challenges, while improving calf growth performance, to improve the economic returns to the dairy calf raiser. Future work should focus on the synchronization of feeding EOC in both the milk replacer and the CS, to determine if further improvements in animal performance can be achieved. Additional research studies may be warranted to evaluate different types of EO (individual or mixture) and optimum dosage of $\mathrm{EO}$ (individual or mixture) to improve growth performance and health.

\section{ACKNOWLEDGMENTS}

The research team greatly expresses their appreciation to the staff at Huajia Dairy Farm Science and Technology Ltd. (Ning Wu and staff) for the use of their facilities and their assistance in carrying out the study. The research team also acknowledges the financial support of this research from the special fund for AgroScientific Research in the Public Interest (201503134) and Gansu Science Foundation (1610RJZA083, Lanzhou, China). Last, the authors gratefully appreciate Ralco Inc. (Marshall, MN) for supplying the product evaluated in this research. The authors have not stated any conflicts of interest.

\section{REFERENCES}

Acamovic, T., and J. D. Brooker. 2005. Biochemistry of plant secondary metabolites and their effects in animals. Proc. Nutr. Soc. 64:403-412. https://doi.org/10.1079/PNS2005449.

AOAC International. 2016. Official Methods of Analysis. 20th ed. AOAC Int., Gaithersburg, MD.

Benchaar, C., S. Calsamiglia, A. V. Chaves, G. R. Fraser, D. Colombatto, T. A. McAllister, and K. A. Beauchemin. 2008. A review of plant-derived essential oils in ruminant nutrition and production. Anim. Feed Sci. Technol. 145:209-228. https://doi.org/10.1016/j .anifeedsci.2007.04.014.

Benchaar, C., J. L. Duynisveld, and E. Charmley. 2006. Effects of monensin and increasing dose levels of a mixture of essential oil compounds on intake, digestion and growth performance of beef cattle. Can. J. Anim. Sci. 86:91-96.

Benchaar, C., and H. Greathead. 2011. Essential oils and opportunities to mitigate enteric methane emissions from ruminants. Anim. Feed Sci. Technol. 166-167:338-355. https://doi.org/10.1016/j .anifeedsci.2011.04.024.

Botsoglou, N. A., P. Floroupaneri, E. Christaki, D. J. Fletouris, and A. B. Spais. 2002. Effect of dietary oregano essential oil on performance of chickens and on iron-induced lipid oxidation of breast, thigh and abdominal fat tissues. Br. Poult. Sci. 43:223-230. https: //doi.org/10.1080/00071660120121436.

Calsamiglia, S., M. Busquet, P. W. Cardozo, L. Castillejos, and A. Ferret. 2007. Invited review: Essential oils as modifiers of rumen microbial fermentation. J. Dairy Sci. 90:2580-2595. https://doi .org/10.3168/jds.2006-644. 
Chapman, C. E., R. G. Cabral, K. M. Aragona, and P. S. Erickson. 2016. Short communication: Cinnamaldehyde taste preferences of weaned dairy heifers. J. Dairy Sci. 99:3607-3611. https://doi.org/ 10.3168/jds.2015-10582.

Franz, C., K. H. C. Baser, and W. Windisch. 2010. Essential oil and aromatic plants in animal feeding - A European perspective. A review. Flavour Frag. J. 25:327-340.

Froehlich, K. A., K. W. Abdelsalam, C. Chase, J. Koppien-Fox, and D. P. Casper. 2017. Evaluation of essential oils and prebiotics for newborn dairy calves. J. Anim. Sci. 95:3772-3782. https://doi.org/ 10.2527/jas.2017.1601.

Gilling, D. H., S. Ravishankar, and K. R. Bright. 2019. Antimicrobial efficacy of plant essential oils and extracts against Escherichia coli. J. Environ. Sci. Health A Tox. Hazard Subst. Environ. Eng. 54:608-616. https://doi.org/10.1080/10934529.2019.1574153.

Hall, M. B. 2009. Analysis of starch, including maltooligosaccharides, in animal feeds: A comparison of methods and a recommend method for AOAC collaborative study. J. AOAC Int. 92:42-49.

He, Z. M., G. P. Li, and D. S. Zhu. 2016. Laboratory animals management and use guidelines. Mammalian experimental animals, sheep. Science Press, Beijing, China.

Hernandez, F., J. Madrid, V. Garcia, J. Orengo, and M. D. Megias. 2004. Influence of two plant extracts on broiler performance, digestibility, and digestive organ size. Poult. Sci. 83:169-174. https:/ /doi.org/10.1093/ps/83.2.169.

Hill, T. M., J. M. Aldrich, R. L. Schlotterbeck, and H. G. I. Bateman II. 2007. Apex plant botanicals for neonatal calf milk replacers and starters. Prof. Anim. Sci. 23:521-526. https://doi.org/10.1532/ S1080-7446(15)31014-7.

Hristov, A. N., C. Lee, T. Cassidy, K. Heyler, J. A. Tekippe, G. A. Varga, B. Corl, and R. C. Brandt. 2013. Effect of Origanum vulgare L. leaves on rumen fermentation, production, and milk fatty acid composition in lactating dairy cows. J. Dairy Sci. 96:1189-1202. https://doi.org/10.3168/jds.2012-5975.

Kertz, A. F., T. M. Hill, J. D. Quigley III, A. J. Heinrichs, J. G. Linn, and J. K. Drackley. 2017. A 100-year review: Calf nutrition and management. J. Dairy Sci. 100:10151-10172. https://doi.org/10 $.3168 /$ jds.2017-13062.

Kolling, G. J., S. C. B. Stivanin, A. M. Gabbi, F. S. Machado, A. L. Ferreira, M. M. Campos, T. R. Tomich, C. S. Cunha, S. W. Dill, L. G. R. Pereira, and V. Fischer. 2018. Performance and methane emissions in dairy cows fed oregano and green tea extracts as feed additives. J. Dairy Sci. 101:4221-4234. https://doi.org/10.3168/ jds.2017-13841.

Lesmeister, K. E., and A. J. Heinrichs. 2004. Effect of corn processing on growth characteristics, rumen development, and rumen parameters in neonatal calves. J. Dairy Sci. 87:3439-3450. https://doi .org/10.3168/jds.S0022-0302(04)73479-7.

Mendel, M., M. Chłopecka, N. Dziekan, and W. Karlik. 2017. Phytogenic feed additives as potential gut contractility modifiers-A review. Anim. Feed Sci. Technol. 230:30-46. https://doi.org/10 .1016/j.anifeedsci.2017.05.008.

National Animal Health Monitoring System (NAHMS). 2016. Dairy 2014: Dairy cattle management practices in the United States, 2014. USDA-APHIS Veterinary Services, Ft. Collins, CO.

NRC. 2001. Nutrient Requirements of Dairy Cattle. 7th rev. ed. Natl. Acad. Press, Washington, DC.

Oba, M., and M. S. Allen. 2003. Effects of corn grain conservation method on feeding behavior and productivity of lactating dairy cows at two dietary starch concentrations. J. Dairy Sci. 86:174183. https://doi.org/10.3168/jds.S0022-0302(03)73598-X.

Ornaghi, M. G., R. A. C. Passetti, J. A. Torrecilhas, C. Mottin, A. C. P. Vital, A. Guerrero, C. Sanudo, M. del Mar Campo, and I. N. Prado. 2017. Essential oils in the diet of young bulls: Effect on animal performance, digestibility, temperament, feeding behavior and carcass characteristics. Anim. Feed Sci. Technol. 234:274-283. https://doi.org/10.1016/j.anifeedsci.2017.10.008.

Pempek, J. A., E. Holder, K. L. Proudfoot, M. Masterson, and G. Habing. 2018. Short communication: Investigation of antibiotic alternatives to improve health and growth of veal calves. J. Dairy Sci. 101:4473-4478. https://doi.org/10.3168/jds.2017-14055.

Poudel, P. 2016. An evaluation of rumen modifiers for lactational performance and nutrient digestibility by cows. MS Thesis. South Dakota State University, Brookings.

Qiao, M., G.-G. Ying, A. C. Singer, and Y.-G. Zhu. 2018. Review of antibiotic resistance in China and its environment. Environ. Int. 110:160-172. https://doi.org/10.1016.j.envint.2017.10.016.

Quigley, J. D. 2019. Symposium review: Re-evaluation of National Research Council energy estimates in calf starters. J. Dairy Sci. 102:3674-3683. https://doi.org/10.3168/jds.2018-15367.

Quigley, J. D., III, Z. P. Smith, and R. N. Heitmann. 1991. Changes in plasma volatile fatty acids in response to weaning and fed intake in young calves. J. Dairy Sci. 74:258-263. https://doi.org/10.3168/ jds.S0022-0302(91)78168-X.

Sakata, T., and H. Tamate. 1979. Rumen epithelial cell proliferation accelerated by propionate and acetate. J. Dairy Sci. 62:49-52. https://doi.org/10.3168/jds.S0022-0302(79)83200-2.

Santos, F. H. R., M. R. De Paula, D. Lezier, J. T. Silva, G. Santos, and C. M. M. Bittar. 2015. Essential oils for dairy calves: Effects on performance, scours, rumen fermentation and intestinal fauna. Animal 9:958-965. https://doi.org/10.1017/S175173111500018X.

Schären, M., C. Drong, K. Kiri, S. Riede, M. Gardener, U. Meyer, J. Hummel, T. Urich, G. Breves, and S. Danicke. 2017. Differential effects of monensin and a blend of essential oils on rumen microbiota composition of transition dairy cows. J. Dairy Sci. 100:27652783. https://doi.org/10.3168/jds.2016-11994.

Stamey, J. A., N. A. Janovick, A. F. Kertz, and J. K. Drackley. 2012. Influence of starter protein content on growth of dairy calves in an enhanced early nutrition program. J. Dairy Sci. 95:3327-3336. https://doi.org/10.3168/jds.2011-5107.

Steel, R. G. D., and J. H. Torrie. 1980. Principles and Procedures of Statistics. 2nd ed. McGraw-Hill Book Co., New York, NY.

Ünal, A., and N. Kocabağli. 2014. Effect of different dosages of oregano oil on performance and some blood parameters in lambs. Veteriner Fakültesi Dergisi. 61:199-204. https://doi.org/10.1501/Vetfak _0000002629.

Vakili, A. R., B. Khorrami, M. D. Mesgaran, and E. Parand. 2013. The effects of thyme and cinnamon essential oils on performance, rumen fermentation, and blood metabolites in Holstein calves consuming high concentrate diet. Asian-Australas. J. Anim. Sci. 26:935-944. https://doi.org/10.5713/ajas.2012.12636.

Van Soest, P. J., J. B. Robertson, and B. A. Lewis. 1991. Methods for dietary fiber, neutral detergent fiber, and nonstarch polysaccharides in relation to animal nutrition. J. Dairy Sci. 74:3583-3597. https://doi.org/10.3168/jds.S0022-0302(91)78551-2.

Varel, V. H. 2002. Livestock manure odor abatement with plant-derived oils and nitrogen conservation with urease inhibitors: A review. J. Anim. Sci. 80(Suppl. 2):E1-E7. https://doi.org/10.2527/ animalsci2002.80E-Suppl_2E1x.

Ye, D., S. K. R. Karnati, B. Wagner, J. L. Firkins, M. L. Eastridge, and J. M. Aldrich. 2018. Essential oil and monensin affect ruminal fermentation and the protozoal population in continuous culture. J. Dairy Sci. 101:5069-5081. https://doi.org/10.3168/jds .2017-13646.

Zhou, R., J. Wu, X. Lang, L. Liu, D. P. Casper, C. Wang, L. Zhang, and S. Wei. 2020. Oregano's impact on in vitro ruminal fermentation, methane production and ruminal microbial community. J. Dairy Sci. 103. https://doi.org/10.3168/jds.2019-16611. 